\title{
Analisis Perbedaan Kinerja Keuangan Perusahaan Pengakuisisi Sebelum Dan Sesudah Akuisisi Periode 2012-2017
}

\author{
Jolly Lim dan Herman Ruslim \\ Program Studi Manajemen, Fakultas Ekonomi dan Bisnis, Universitas Tarumanagara, \\ Jakarta \\ Email: jolly.lim@yahoo.com
}

\begin{abstract}
Abstrak: Akuisisi merupakan salah satu bentuk strategi perusahaan dengan tujuan memperoleh keuntungan. Keuntungan yang diperoleh, diharapkan dapat memberikan dampak positif bagi kedua perusahaan. Keuntungan tersebut akan terjadi apabila kegiatan akuisisi ini memperoleh sinergi, akibat dari sinergi perusahaan ini diharapkan akan meningkatkan kinerja keuangan perusahaan. Penelitian ini dilakukan dengan tujuan untuk menganalisis perbedaan kinerja keuangan perusahaan sebelum dan sesudah akuisisi pada perusahaan pengakuisisi. Kinerja keuangan perusahaan diukur dengan menggunakan rasio keuangan yaitu return on equity sebagai alat ukur profitabilitas, fixed asset turnover sebagai alat ukur aktivitas, debt to asset ratio sebagai alat ukur solvabilitas dan quick ratio sebagai alat ukur likuiditas. Penelitian ini dilakukan pada perusahaan yang melakukan kegiatan akuisisi pada periode 2012-2017 dan terdaftar di BEI (Bursa Efek Indonesia). Pengambilan sampel dilakukan dengan mengunakan metode purposive sampling denga data yang diperoleh sebanyak 30 perusahaan yang melakukan kegiatan akuisisi dan mengolah data dengan menggunakan software SPSS 26. Pengujian non parametric yang digunakan adalah statistik deskriptif dan wilcoxon signed rank test untuk menjawab hipotesis. Adapun hasil penelitian ini adalah rasio profitabilitas tidak terdapat perbedaan yang signifikan, pada rasio aktivitas tidak terdapat perbedaan yang signifikan, pada rasio solvabilitas terdapat perbedaan yang signifikan dan tidak terdapat perbedaan yang signifikan pada rasio likuiditas. Namun dalam pengujian statistik deskriptif rasio fixed asset turnover, debt to asset ratio, dan return on equity menuju kearah positif setelah dilakukannya kegiatan akuisisi yang menunjukan adanya sinergi yang diperoleh perusahaan pengakuisisi setelah melakukan akuisisi
\end{abstract}

Kata kunci: akuisisi, kinerja keuangan, kuantitatif, wilcoxon signed rank test, statistik deskriptif 


\begin{abstract}
Acquisition is one of corporate strategy with the aim of gaining profits. The benefits obtained are expected to have a positive impact not just on one side of companies but on both companies. An advantage situation will occur when merger and acquisition activity is gaining synergies, as a result of corporate synergies expected to improve the performance of the company. This study aims to analyze the differences in firm performance before and after mergers and acquisitions on corporate merger and acquisition activity. Corporate performance is measured by using financial ratio: return on equity as a measure of profitability, fixed asset turnover as measure of activity, debt to asset ratio as measure of solvency and quick ratio as measure of liquidity. Quantitative methods is used in this study, take the data from all public companies doing acquisitions in Indonesia Stock Exchange (IDX) with the period 2012 to 2017. Sampling in the study using purposive sampling method, with data obtained by 30 corporate acquisitions. Nonparametric test used was the Statistic Descriptives and Wilcoxon Signed Ranks Test to answer the hypothesis. The results of this study are that there are no significant differences in profitability ratios, in the activity ratios there are no significant differences, in solvability ratios there are significant differences, and there is no significant differences in liquidity ratios. But in descriptive statistic testing the ratio of fixed asset turnover, debt to asset ratio, and return on equity is headed towards positive after the acquisition activity that shows the synergy obtained by the acquiring company after making acquisition.
\end{abstract}

Keywords: acquisition, financial performance, quantitative, wilcoxon signed rank test, descriptive statistics

\title{
LATAR BELAKANG
}

Sebuah perusahaan tidak lepas dari persaingan yang semakin tinggi, oleh karena itu perusahaan didorong untuk terus berkembang dan bertahan ditengah persaingan. Salah satu strategi yang digunakan perusahaan untuk bertahan adalah akuisisi. akuisisi merupakan bentuk penggabungan dua usaha yang bertujuan untuk memperoleh keuntungan.

Keuntungan tersebut akan diperoleh apabila penggabungan usaha ini menghasilkan sinergi. Tetapi pada kenyataannya dalam melakukan kegiatan akuisisi tidak semuanya memperoleh sinergi, banyak perusahaan pengakuisisi yang melakukan kegiatan akuisisi semata-mata hanya untuk menyelamatkan perusahaan yang akan financial distress dan keuntungan yang diperoleh dapat berupa bebas biaya pajak dan biaya operasional yang lebih rendah.

Untuk mengetahui apakah penggabungan usaha tersebut memperoleh sinergi atau tidak dengan melihat kinerja keuangan perusahaannya. Banyaknya peneliti terdahulu meneliti tentang penggabungan usaha ini dan hasil yang diperoleh berbeda-beda.

Ada yang kinerja keuangannya meningkat setelah melakukan akuisisi, ada kinerja keuangannya yang sama sekali tidak mengalami perubahan (hanya sedikit), dan ada yang kinerja keuangannya tidak meningkat setelah melakukan akuisisi. 
Berdasarkan uraian latar belakang di atas maka peneliti tertarik untuk mengkaji kembali apakah terdapat perbedaan kinerja keuangan perusahaan setelah melakukan akuisisi. oleh karena itu judul penelitian yang akan diteliti adalah "Analisis Perbedaan Kinerja Keuangan Perusahaan Pengakuisisi Sebelum dan Sesudah Akuisisi Periode 20122017"

\section{KAJIAN TEORI}

Menurut Wijoyono dan Kusuma (2017:349) akuisisi diartikan sebagai pengambilalihan kepemilikan dan kontrol manajemen oleh satu perusahaan dengan perusahaan lain. Jadi dua perusahaan bergabung hanya berdiri dalam badan hukum yang berbeda dan perusahaan yang mengakuisisi bertindak sebagai perusahaan induk.

Keberhasilan suatu proses dari akuisisi dapat dilihat dari kinerja keuangan perusahaannya, kinerja keuangan dapat diartikan sebagai prestasi manajemen. Dalam hal ini tujuannya adalah memperoleh keuntungan dan meningkatkan nilai perusahaan.

Dalam penelitian ini peneliti menggunakan empat rasio keuangan yang mewakili kinerja keuangan perusahaan terdiri dari rasio profitabilitas yang diproksikan dengan return on equity, rasio aktivitas yang diproksikan dengan fixed asset turnover, rasio solvabilitas yang diproksikan dengan debt to asset ratio dan rasio likuiditas yang diproksikan dengan quick ratio.

Dalam uraian tersebut, maka dapat disimpulkan kerangka pemikiran sebagai berikut:

\section{Gambar 2.3 Kerangka Pemikiran}

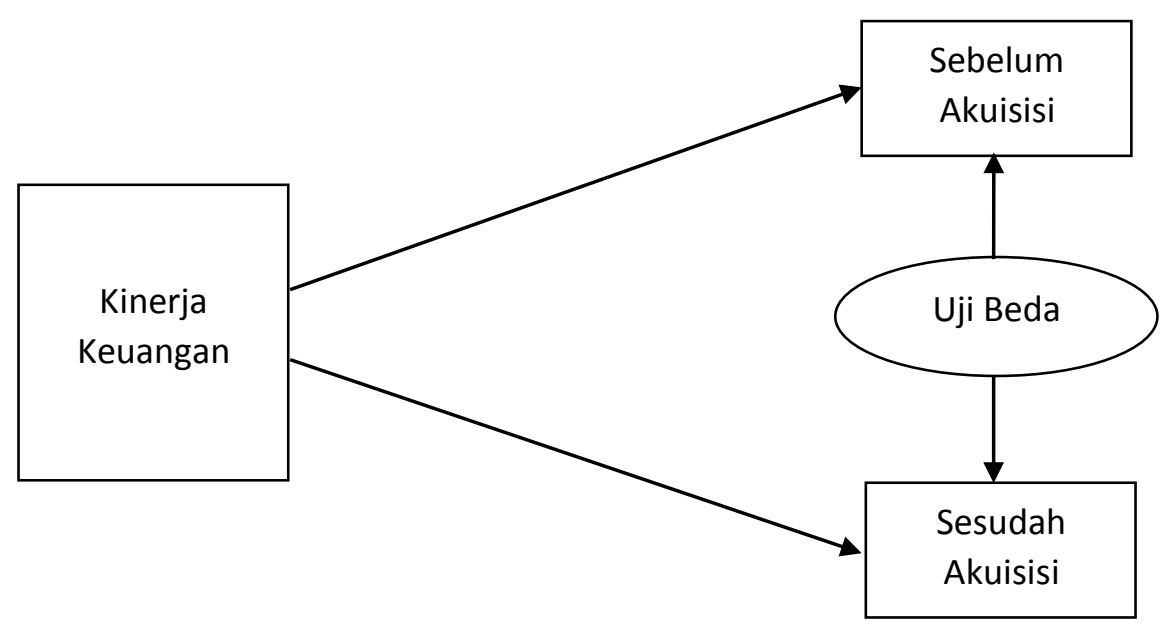

H1: Terdapat perbedaan secara signifikan pada return on equity baik sebelum dan sesudah akuisisi 
Berdasarkan penelitian yang dilakukan oleh Kadek Hendra Gunawan dan I Made Sukharta (2013) rasio profitabilitas yang diproksikan dengan return on equity mengalami peningkatan yang signifikan pasca merger dan akuisisi

$\mathrm{H} 2$ : Terdapat perbedaan yang signifikan pada debt to asset ratio baik sebelum dan sesudah akuisisi

Berdasarkan penelitian yang dilakukan oleh Pivi Princifal Yosefa Tarigan dan Wahyu Ario Tarigan (2015) menyatakan bahwa terdapat perbedaan yang signifikan pada debt to asset ratio baik sebelum dan setelah akuisisi

H3: terdapat perbedaan yang signifikan pada fixed asset turnover baik sebelum dan sesudah akuisisi

Berdasarkan penelitian yang dilakukan oleh Linda Finansia (2017) menyatakan bahwa fixed asset turnover tidak menunjukan perbedaan yang signifikan baik sebelum dan setelah akuisisi

H4: terdapat perbedaan yang signifikan pada quick ratio baik sebelum dan sesudah akuisisi Berdasarkan penelitian yang dilakukan oleh Ira Fuji Jaya Lesmana dan Ardi Gunardi (2012) memperoleh hasil quick ratio mengalami peningkatan sebesar 5,1\%

\section{METODOLOGI}

Desain penelitian yang digunakan adalah kuantitatif. Penelitian ini memuat kinerja keuangan dengan empat rasio keuangan antara lain return on equity, debt to asset ratio, fixed asset turnover, dan quick ratio sebagai variabel independen dan akuisisi sebagai variabel dependen.

Populasi dalam penelitian ini adalah perusahaan yang melakukan kegiatan akuisisi pada periode 2012-2017 dengan mengambil sebanyak 30 perusahaan yang melakukan kegiatan akuisisi.

Teknik pengambilan sampel yang dilakukan menggunakan teknik purposive sampling dengan kriteria perusahaan melakukan kegiatan akuisisi pada periode 2012-2017 dan diumumkan secara jelas, laporan keuangan yang dibutuhkan oleh peneliti lengkap selama periode penelitian dilakukan.

Analisis yang digunakan dalam penelitian ini adalah statistik deskriptif, uji normalitas dengan saphiro-wilk dan pengujian hipotesis dengan wilcoxon signed rank test. 


\section{HASIL ANALISIS DATA}

Hasil uji statistik deskriptif untuk mengetahui nilai rata-rata, nilai minimum dan nilai maximum baik sebelum dan sesudah akuisisi.

Tabel 4.1

Hasil Uji Statistik Deskriptif

\begin{tabular}{|l|c|c|c|c|}
\hline \multicolumn{5}{|c|}{ Descriptive Statistics } \\
\hline & $\mathrm{N}$ & Minimum & Maximum & Mean \\
\hline QR_sebelum & 30 &, 1600 & 6,7900 & 2,003333 \\
\hline QR_sesudah & 30 &, 1600 & 7,8400 & 1,554667 \\
\hline FATO_sebelum & 30 &, 0400 & 65,5700 & 6,147000 \\
\hline FATO_sesudah & 30 &, 0500 & 116,7500 & 7,477000 \\
\hline DAR_sebelum & 30 &, 0600 &, 6800 &, 369000 \\
\hline DAR_sesudah & 30 &, 0700 & 4,1800 &, 582333 \\
\hline ROE_sebelum & 30 &, 0000 &, 6000 &, 142333 \\
\hline ROE_sesudah & 30 &, 0000 &, 8200 &, 144000 \\
\hline Valid N (listwise) & 30 & & & \\
\hline
\end{tabular}

Berdasarkan hasil uji statistik deskriptif dilihat dari rata-ratanya bahwa nilai quick ratio menurun setelah akuisisi dari 2,00 menjadi 1,55. Nilai rata-rata fixed asset turnover meningkat setelah akuisisi dari 6,15 menjadi 7,48 . Nilai rata-rata debt to asset ratio meningkat setelah akuisisi dari 0,37 menjadi 0,58 . Sedangkan nilai rata-rata return on equity tidak mengalami peningkatan maupun penurunan.

Tabel 4.2

Hasil Uji Normalitas

\begin{tabular}{|c|c|c|c|c|c|c|c|}
\hline \multicolumn{8}{|c|}{ Tests of Normality } \\
\hline & \multicolumn{3}{|c|}{ Kolmogorov-Smirnov ${ }^{\mathrm{a}}$} & \multicolumn{3}{|c|}{ Shapiro-Wilk } & \multirow{2}{*}{$\begin{array}{c}\text { Keteran } \\
\text { gan }\end{array}$} \\
\hline & Statistic & df & Sig. & Statistic & df & Sig. & \\
\hline $\begin{array}{l}\mathrm{QR} \\
\text { sebelum }\end{array}$ & .182 & 30 & .012 & .826 & 30 & .000 & $\begin{array}{c}\text { Tidak } \\
\text { normal }\end{array}$ \\
\hline $\begin{array}{l}\text { QR } \\
\text { sesudah }\end{array}$ & .299 & 30 & .000 & .690 & 30 & .000 & $\begin{array}{c}\text { Tidak } \\
\text { normal }\end{array}$ \\
\hline $\begin{array}{l}\text { FATO } \\
\text { sebelum }\end{array}$ & .350 & 30 & .000 & .431 & 30 & .000 & $\begin{array}{c}\text { Tidak } \\
\text { normal }\end{array}$ \\
\hline
\end{tabular}


Lim dan Ruslim: Analisis Perbedaan Kinerja Keuangan Perusahaan...

\begin{tabular}{|l|c|c|c|c|c|c|c|}
\hline $\begin{array}{l}\text { FATO } \\
\text { sesudah }\end{array}$ & .415 & 30 & .000 & .330 & 30 & .000 & $\begin{array}{c}\text { Tidak } \\
\text { normal }\end{array}$ \\
\hline $\begin{array}{l}\text { DAR } \\
\text { sebelum }\end{array}$ & .122 & 30 & $.200^{*}$ & .951 & 30 & .175 & Normal \\
\hline $\begin{array}{l}\text { DAR } \\
\text { sesudah }\end{array}$ & .302 & 30 & .000 & .507 & 30 & .000 & $\begin{array}{c}\text { Tidak } \\
\text { normal }\end{array}$ \\
\hline $\begin{array}{l}\text { ROE } \\
\text { sebelum }\end{array}$ & .164 & 30 & .039 & .830 & 30 & .000 & $\begin{array}{c}\text { Tidak } \\
\text { normal }\end{array}$ \\
\hline $\begin{array}{l}\text { ROE } \\
\text { sesudah }\end{array}$ & .234 & 30 & .000 & .708 & 30 & .000 & $\begin{array}{c}\text { Tidak } \\
\text { normal }\end{array}$ \\
\hline
\end{tabular}

Berdasarkan pada tabel 4.2 terdapat dua kategori dalam pengujian normalitas yaitu kolmogorov-smirnov dengan saphiro-wilk karena data sampel yang digunakan oleh peneliti tidak besar (kurang dari 50) maka tabel yang diperhatikan adalah pada tabel saphiro-wilk. Diperoleh hasil melalui hasil uji normalitas bahwa quick ratio sebelum dan sesudah akuisisi tidak normal, fixed asset turnover sebelum dan sesudah akuisisi tidak normal, debt to asset ratio sebelum akuisisi normal sesudah akuisisi tidak normal, dan return on equity sebelum dan sesudah akuisisi tidak normal.

Tabel 4.3

Hasil Uji Wilcoxon Signed Rank Test

\begin{tabular}{|c|c|c|c|}
\hline Variabel & Z-hitung & $p$-value & Keterangan \\
\hline Return on Equity & $-0,365$ & 0,715 & Ha ditolak \\
\hline $\begin{array}{c}\text { Fixed Asset } \\
\text { Turnover }\end{array}$ & $-1,635$ & 0,102 & Ha ditolak \\
\hline $\begin{array}{c}\text { Debt to Asset } \\
\text { Ratio }\end{array}$ & $-2,65$ & 0,008 & Ha diterima \\
\hline Quick Ratio & $-1,286$ & 0,199 & Ha ditolak \\
\hline
\end{tabular}

Berdasarkan tabel 4.3 bahwa peneliti menggunakan pengujian wilcoxon signed rank test pada data yang memberikan hasil uji normalitas tidak normal. Diperoleh nilai z-hitung return on equity sebesar $-0,365$ dengan nilai signifikansi 0,715 . Karena nilai signifikansi lebih besar dari 0,05 maka $\mathrm{Ha}$ ditolak atau $\mathrm{H}_{0}$ diterima. Hal ini berarti akuisisi tidak memberikan perbedaan yang signifikan pada rasio return on equity. nilai z-hitung dan signifikansi fixed asset turnover masing-masing -1,635 dan 0,102. Nilai signifikansi lebih besar dari 0,05 maka $\mathrm{Ha}$ ditolak dan $\mathrm{H}_{0}$ diterima yang artinya akuisisi tidak memberikan perbedaan yang signifikan pada rasio fixed asset turnover. Nilai z-hitung dan signifikansi 
pada debt to asset ratio masing-masing -2,65 dan 0,008. Nilai signifikansi yang diperoleh lebih kecil dari 0,05 maka $\mathrm{Ha}$ diterima dan $\mathrm{H}_{0}$ ditolak yang artinya akuisisi memberikan perbedaan yang signifikan pada rasio debt to asset ratio. Nilai z-hitung dan signifikansi pada quick ratio masing-masing -1,286 dan 0,199. Nilai signifikansi yang diperoleh lebih besar dari 0,05 maka Ha ditolak dan $\mathrm{H}_{0}$ diterima yang artinya akuisisi tidak memberikan perbedaan yang signifikan pada rasio quick ratio.

\section{DISKUSI}

Penelitian ini bertujuan untuk mengetahui apakah terdapat pengaruh yag positif atau negatif antara kinerja keuangan perusahaan pengakusisi dengan kegiatan akuisisi. Apabila hasil signifikansi lebih besar dari 0,05 maka akuisisi tidak memberikan perbedaan yang signifikan pada kinerja keuangan perusahaan pengakuisisi sebaliknya apabila signifikansi lebih kecil dari 0,05 maka akuisisi memberikan perbedaan yang signifikan pada kinerja keuangan perusahaan pengakuisisi.

Kesimpulan yang diperoleh dari hasil penelitian bahwa tidak terdapat perbedaan yang signifikan pada rasio profitabilitas yang diproksikan dengan return on equity, tidak terdapat perbedaan yang signifikan pada rasio akivitas yang diproksikan dengan fixed asset turnover, terdapat perbedaan yang signifikan pada rasio solvabilitas yang diproksikan dengan debt to asset ratio, tidak terdapat perbedaan yang signifikan pada rasio likuiditas yang diproksikan dengan quick ratio.

\section{PENUTUP}

Dalam penelitian ini terdapat beberapa saran yang sekiranya dapat bermanfaat bagi peneliti selanjutnya, bagi investor dan calon investor, dan bagi perusahaan:

a. Bagi peneliti selanjutnya

Disarankan untuk memperpanjang periode penelitian peristiwa akuisisi dengan menggunakan alat uji statistik yang berbeda sehingga dapat melihat perbedaan dari sisi lain selain dari penelitian ini serta menambah jumlah sampel perusahaan yang diteliti.

b. Bagi investor dan calon investor

Sebelum investor melakukan investasi pada perusahaan yang baru saja melakukan aktivitas akuisisi akan lebih baik untuk memperhatikan kondisi keuangan perusahaan pada saat setelah melakukan akuisisi, karena tidak selalu akuisisi memberikan dampak yang baik bagi perusahaan yang melakuka akuisisi.

c. Bagi perusahaan

Disarankan bagi perusahaan yang akan melakukan akuisisi untuk memperhatikan perusahaan target baik dari segi operasional ataupun dari segi keuangannya karena tujuan utama dari akuisisi adalah sinergi. 


\section{DAFTAR PUSTAKA}

Finansia, L. (2014). Analisis Kinerja Keuangan Perusahaan Sebelum dan Setelah Merger dan Akuisisi. 43-54.

Gunawan, K. H., \& Sukartha, I. M. (2013). Kinerja Pasar dan Kinerja Keuangan Sesudah Merger dan Akuisisi Di Bursa Efek Indoneisa. E-jurnal Akuntansi Universitas Udayana,271-290.

Kuncoro, W. H. (2014). Analisis Pengaruh Merger dan Akuisisi Terhadap Kinerja Keuangan Perusahaan (Studi Kasus pada Perusahaan yang Terdaftar di Bursa Efek Indonesia Periode 2004-2013).

Lesmana, F. J., \& Gunardi, A. (2012). Perbedaan Kinerja Keuangan dan Abnormal Return Sebelum dan Sesudah Akuisisi di BEI. Trikonomika, 11, 2nd ser., 195-211.

Resvika, R. D., Sari, Salim, M. A., \& Wahono, B. (2018). Analisis Perbedaan Harga Saham Perusahaan Sebelum dan Sesudah Akuisisi (Studi Empiris Pada Perusahaan yang Terdaftar di BEI Periode 2013-2017). E-jurnal Riset Manajemen,11-20.

Utami, S. B., Warnaningtyas, H., \& Suyanto, M. N. (2014). Analisis Dampak Akuisisi Terhadap Kinerja Keuangan Perusahaan Pengakuisisi (Studi Kasus Pada Perusahaan Go Public di Bursa Efek Indonesia). Ekomaks,3, 1st ser., 77-90.

Yosefa, P. P., Tarigan, \& Pratomo, W. A. (2015). Analisis Dampak Merger dan Akuisisi Terhadap Abnormal Return dan Kinerja Keuangan Pada Perusahaan yang Terdaftar di Bursa Effek Indonesia. Jurnal Ekonomi Dan Keuangan,3, 3rd ser., 200-212. 